\title{
The resistance of urban poor upon the modern medication system: Reaction towards the power domination practice of the medical regime
}

\author{
Resistensi masyarakat miskin di perkotaan terhadap sistem pengobatan \\ modern: Studi tentang reaksi urban poor atas praktik dominasi kekuasaan \\ rezim medis di Kota Surabaya
}

\author{
Septi Ariadi, Partini \& Mohammad Supraja \\ Study Program of Doctorate of Sociology, Faculty of Social and Politics, \\ Gadjah Mada University
}

\begin{abstract}
The power domination that reflected in the form of dominant discourse and normality management done by the medical regime through the hegemony process and the panoptic mechanism upon the individual and society in concrete is marked by the presence of regulation and surveillance (monitoring) in the medical fields. This study focuses the attention on the attempt in understanding and analyze the process and the resistance of urban poor upon the modern medication system that is internalized by medical regime as well as to explain the base or the potential problem that could become the trigger for the occurrence of resistance. This study also discuss the power relation that is made with the health personnel as well as to identify the base or the background that causing the resistance. This study used the qualitative-inductive method and the reflexive methodology. With the critical perspective and using the reflexive methodology from this study, conclusion can be drawn the power domination that is demonstrated by the medical regime has create the critical awareness of the urban poor that is followed by the process of resistance that is realized in the technique of low profile by avoiding, retracting, fatalist and passive. All of that is according to the characteristics of the low class structure as well as the resistance that is personal, spontaneous, and expressive; that tend to be manifested as well as exit and developed an alternative discourse/ otherness according to the autonomy of willingness and power owned by the urban poor. In the context of resistance act of urban poor is realized in three shapes: (a) urban poor developed skepticism and criticism upon the modern medication although they still accessing the modern medication, (b) developed the pluralistic-patterned medical orientation or the combinative one. Lastly, (c) the exit of urban poor and developed the alternative discourse/otherness about the medication system to gain the recovery according to the autonomy of willingness and power held by it.
\end{abstract}

Keywords: dominant, power, hegemony, modern medication, resistance, urban poor

\begin{abstract}
Abstrak
Dalam sosiologi kesehatan analisis kritis terhadap bekerjanya sistem, struktur dan institusi medis merupakan fokus kajian yang menarik utamanya dalam konteks govermentality nilai-nilai medis modern rezim medis. Dominasi kekuasaan yang direfleksikan dalam bentuk diskursus dominan dan menajemen kenormalan yang dilakukan melalui proses hegemoni dan mekanisme panopticsm rezim medis terhadap individu dan masyarakat secara konkrit ditandai oleh adanya regulasi dan surveilans (pengawasan) dalam bidang medis. Tulisan ini memfokuskan perhatian pada upaya memahami dan menganalisis proses berlangsungnya dan bentuk resistensi urban poor atas sistem pengobatan modern yang diinternalisasikan rezim medis serta menjelaskan basis atau potensial problematic yang menjadi triger bagi terjadinya resistensi. Secara ringkas tulisan ini bermaksud memperluas khasanah riset empiris terkait resistensi urban poor atas sistem pengobatan modern terutama medical health care dan relasi kuasa yang terjalin dengan health personal serta mengidentifikasi basis atau latar belakang penyebab berlangsungnya resistensi sehingga dapat menjadi bahan bagi terkonstruksinya sejumlah implikasi teoritik dan implikasi praktis bagi upaya perbaikan pelayanan medis modern ke depan. Dengan perspektif kritis dan menggunakan reflexive methology dari studi ini dapat disimpulkan bahwa dominasi kuasa yang didemontrasikan rezim medis telah melahirkan kesadaran kritis urban poor yang diikuti oleh berlangsungnya resistensi yang terwujud dalam teknik low profile dengan menghindar, menarik diri, fatalis dan pasif sesuai dengan ciri struktur kelas bawah serta resistensi yang bersifat personal, spontan dan ekspresif yang cenderung bersifat manifest serta keluar (exit) dan membangun diskursus alternative/wacana lain (otherness) sesuai otonomi kehendak dan kuasa yang dimiliki urban poor.
\end{abstract}


Keyword: hegemony, panopticism, rezim medis, urban poor, pengobatan modern, resistensi, dominant power

\section{Introduction}

The transition of thought about the medication system from the traditional ones to the modern medication one that happened from the Age of Enlightenment in circa $18^{\text {th }}$ century that is signed with the rational methodological way of thinking as well as to prioritize the advancement of diagnostics technology. It has caused the birth of new paradigm in the dealing with the health issues including in dealing the cause of health issues and the invention of new medicine as well as prevention method (Yen 2009). For the medical regime, the advancement of science and technology in medics through the invention and the application of modern technology of genetic engineering, advance biological monitoring tools, organ transplantation methods and various modern medical tools is seen positively as the media that is believed to be able to solve the health issue (Nugroho 2011). Based on this belief, the medical regime internalized the modern medical medication so it can be practiced so that "normality" and "health status" can be achieved so that the society can act productively as well as beneficial in their life.

The internalization of norms of hygiene and the coordination upon the public health is kept on practiced, the administrative structure of the medical regime is developed so that the individual that is trapped in the administrative culture and trapped inside the iron cage of rational bureaucracy (Weber 1978). The society is positioned as the object that is countable, monitored and surveyed. Discipline keeps developed with the purpose to predict and control the behavior of individual as well as to give the information to the nation so that they can control and monitor the society (White 2011). Through the bureaucracy and the institution of medical regime, they can do some regulating and surveilling including upon the centralization of information about the condition especially for the importance of social planning in relation to the health issue (Foucault 1973). The thought of the medical regime like such, in the end, leads to the definition of health and sick, normal and not normal that has to be in sync with the standard of modern health that is developed by the medical regime according to the willingness, authorities and its power.

The strengthening of the internalization system of the modern medication is done intensely through the production of literature in the development program and the health service, such as in Jamkesmas, Jakesda, JKN, BPJS, health funding subsidiary, the repairing of the health management and many others. In term of juridical, the government has issued the Presidential Regulation No. 72 of 2012 about the National Health System (SKN) with the purpose to grow the awareness and to instill the modern health values that is strengthened by the instrument of regulation and social practices. In Surabaya City, the regulations about health have been issued many times, such as the Regional Regulation No. 5 of 2010 about the Retribution of the Health Service to Public Health Agency of Surabaya City, City Mayor Regulation No. 69 of 2008 about the UPTD of Health Laboratory on DKK, City Mayor Regulation No. 11 of 2012 about the UPTD of Health Pharmaceutical Warehouse, City Mayor Regulation No. 27 of 2012 about the Local Health Clinic (Puskesmas), City Mayor Regulation No. 73 of 2012 about the provision of goods and services, even the City Mayor Regulation No. 35 of 2014 about the Health Insurance for the Poor People that is funded by the Regional Budgeting of Income and Spending (APBD) of Surabaya City. To support and realize the development of the modern health in Surabaya City on 2015, the government has allocated budgeting in health sector that is gained from the APBD of the city, APBD of the province, APBN, help from the foreign sectors, and other sources that in total is as much as IDR 1.204.897.887.835. The health budgeting from the APBD of the city of Surabaya in itself is $12,77 \%$ from the total of APBD spent on city of Surabaya (Public Health Agency of Surabaya City of 2015). Even, the attention to the urban poor is also given by the media of medical regulation that made that is the City Mayor Regulation No. 35 of 2014 about the Health Insurance for the Poor People that is Funded by the Regional Budgeting of Income and Spending (APBD) of Surabaya City with the expectation that the urban poor may access the facility of the modern medical treatment. 
This reality shows that the seriousness of the medical regime in Surabaya City in growing the culture of the modern medication system. However, the question is will the social practice of the medical world upon the urban poor will always obey and following the authority of the medical regime? This critical question rises considering the presence of some social reality phenomena, such as (a) the dominant authority that will always take control as well as did not give any space of freedom and tend to potentially creating resistance of the individual through the self-awareness or the technology of the self, (b) Resistance may occur because of the socio-culture and the economy of the urban poor that has the various character such as: value system, social relation, way of thinking, experience, perception about the modern medical treatment that may not be suitable with the willingness of the medical regime, (c) the presence of the skepticism and the distrust upon the modern medical treatment as well as the hardship of the urban poor in accessing BPJS that is seen too bureaucratic and economically burdening meanwhile, daily, they need to face limitations, such as low income and level of education, weak or even having no bargaining position at all, weak physical condition, isolated from the information and development program as well as vulnerability, and many more (Chambers 1997), (d) The presence of the social relation that is asymmetric and also dominative so that the relation that is going is even will create a depowering upon the patients when they do some interaction with the health personnel and the medical institution (Nugroho 2011), (e) the presence of doubt upon the effectiveness of the modern medication. Illich (1976) stated that in the process of medical treatment done by the health personnel is not necessarily always effective even potentially creating new social sickness such as: Clinical iatrogenic, social iatrogenic, and structural iatrogenic including the use of wrong medicine, poisoning, giving side effects because the medical personnel that is not professional, reckless, failed to focus and underestimating any medical treatment so that malpractices might happen (Meyler 1972). (f) The presence of suspicion of business practice of doctor that is implicit hidden behind the practice of modern medication system done by the medical agency and the medical apparatus with the pharmaceutical industry. The chance of the medical workers to do some moral hazard even fraud is highly possible to happen through giving prescription of medicine to aim commission from the pharmaceutical industry supplying certain medicine or th instruct the patient to undergo surgery meanwhile the sickness is not really chronic.

For the urban poor, choosing medication system cannot entirely be simplified through some thinking about the regulation and the completeness if the medical facility as well as the ease of access upon the medication cost as thought by the medical regime. Despite of all that is covered through the regulation and funding from the APBD, yet the urban poor feel that the system of the modern medication still suffer the weakness or the modernity pathology due to the treatment received by the urban poor such as: discriminative treatment, isolation from the medical information, getting complication in the bureaucracy of the modern medical treatment and so on (Jeniet 2010). For the poor people, the modern medical treatment often seen to still suffer a number of problem such as: complicated administration, the presence of additional payment in dealing with the administration, arrogant and anti-critics service, lacking in wise response, discriminative treatment, ignored and given more difficulties in the hospital service (Putra 2012).

Based on the background of problem mentioned then this study is done with these goals: 1) to understand and analyze the process of the resistance happened to the urban poor upon the modern medication system of the medical regime. 2) Identifying form and the bases or the background of the cause of why resistance happened to the urban poor upon the modern medical system done by the medical regime.

For the sake of understanding and doing the analysis upon this social reality about the resistance of urban poor upon the modern medical system, this study using the perspective of critical theory that focuses to the issues about the exploitation, marginalization, the inability and so on that prioritize the tendency without omitting objectivity by opening the curtain and explain the root of the problem in depth (Agger 2009). In the book entitled "The Birth of The Clinic" (1976), Foucault has criticized the institution of hospital that done the practice pf power on the patients through the good values according to the knowledge of medic. According to Foucault, there have been some changes in the 
science of medic, from the one that focuses on the health and still provide spaces for the patient to be their self-doctor on the $18^{\text {th }}$ century, to the condition where the conception of medical science that focuses on the normality where the body of the patient is the subject of the doctor that has a great sovereignty in the system of a modern hospital. On a broader scale, the domination of the medical regime is practiced through the flow of thinking of governmentality that is moved by the net of power of the government through the presence of standard of truth in medic through the processes such as clarification, simplification, control, effectiveness, and management in order to rule the people achieve the goal of government that is to create a healthy and qualified society. Meanwhile, in the context of micro power, Foucault (1997) mentioned that in the medical world, body and health is the region where the relation between powers happen on top of it. The relation of these powers work and show itself in the activity of train, force, torture, mark, instill, the power and ruling the body. The body becomes the strength as long as it becomes the body that is obey and productive one. The ruling of one body becomes the knowledge upon the body. The ruling and the knowledge about body uphold the political technology upon the body (Hardiyanto 1997).

Foucault mentioned that the power is plural and is not centralistic and can be found everywhere (Piliang 2004). The power can infiltrate to various aspects of life as well as absorbed inside the knowledge and is a set of disciplines, connected with the networks, gives the structure of activities, not being repressive and productive instead as well as sticking on the willingness to find out the next in creating the regime of truth that often realized in the form of discourse. Discourse can give the implication on the importance of power, hegemony, cultural domination as well as the science about the human body. The presence of rules and normalization that is done by the medical regime in the attempt of increasing the status or degree of the public health, decrease the number death rate of mother and baby, suggesting in making use if the health service with the medical workers, examining the health condition that is suggested to go to medical practitioners or the medical workers are some of the regulation that will always be introduced by the government through the medical officers and the health institution in the sub-district as well as the city level. With the mechanism and strategy of ruling, then we will be able to shape every individual to have the self-discipline so that they may be able to become a productive individual. According to Foucault (1979), the power must always be articulated through knowledge, and the knowledge always has the effect of power. Hence, to find out the power needed for the research about the production of knowledge that found the power. It is because the power is not understood as something that comes naturally as the abstract concept but is produced by every power instead.

"Power creates knowledge. Power and knowledge is directly influencing each other.. there is no relation in power without any correlative constitution from the field of knowledge..." (Foucault 1979).

What Foucault wishes to deconstruct is how the people set or to self-regulate themselves and others to create the claim of truth (a confirmation of an absolute correct-wrong, good-bad, beauty-ugly) can be made to be orderly, sturdy, and stable. Hence, Foucault believed that power does not work through repression, but through a positive and productive manner instead. Power does not always work through violence, instead it works through normalization and regulation (Sutrisno 2005).

Although in the medical world the mechanism of panoptic has the power in creating discipline by doing monitoring, surveillance upon behavior, as well as the lifestyle of individual, yet will the individual always be obey and following the power of the medical regime? Foucault (1984) mentioned that the power as the domination system tend to have control upon everything and does not leave any room for freedom, while inside every individual, basically, has the ability to do some resistance upon the dominant discourse that will always try to create discipline and doing control upon any act of individual. Because of the basic characteristics of power that tends to be dominant, then it will create implication to the possibility of the rise of resistance (Dumm 1996). In the relation between power and resistance, it is highly possible for self-awareness to occur in individual as the 
subject through the process of understanding upon oneself or the technology of the self. Resistance upon the modern medication as the dominant discourse that is developed by the medical regime will potentially occur inside the mind of individual as the result empty spaces different values believed or the ideology that sticks inside the mind of individual, in the reality, it is inevitable that socioculturally and economically urban poor has various character and hence the potential of resistance to occur is very high. The value system, social relationship, way of thinking, experience, perception about the modern medical services that have been accessed will give various reaction spectrum upon the medical regime. Resistance is also part from the relationship between power and the fight occur from different places and move as the dynamic of power changes (Martono 2014).

In the practice of social, the resistance process usually began by the presence of critical consciousness. Critical consciousness will direct human to the process of human liberation from the domination, injustice and exploitation as well as from the dependency including the dependency upon the modern medical regime. For the subordinated class and the lower class, the phenomena of resistance is the reality that is commonly occur. Usually, resistance is seen to have the characteristic of cultural because resistance occur through the daily expression as well as act from the people. Resistance can happen if the intervention from the state is not in accordance with the norm in the life of the society so that it cannot be accepted well, also because of local event and the condition of the feeling and the experiences of the subjective individual. The form of the resistance done by the minority, the weak, are relatively varied, such as: low-profile technique, partial hide and evade, foot-dragging evasion and open rejection or struggle (Scott 1985). Systematically, Scott (1985) mentioned that the resistance done the people can be in a form of a closed one that is symbolical or ideological, like gossip, slander, refusal upon the categories that is forced to the society as well as the recall of the respect for the authority. Semi-open resistance (social protest or strike) and open resistance is the form of resistance that is organized, systematic and having principle. The manifestation used in the resistance is by violence such as rebellion. At the end, the approach upon the local-level study and the forms might be worth in understanding the dynamic of the development including inside the medical world. In the daily life, not all kind of fight must be open because indeed unconsciously a fight is done quietly (Suriadi 2008). Even sometimes the subordinate level seemed to show the obedience to the rules, norms and policies that is shaped by the authority level to avoid risks and to seek safety yet basically there is informal interaction that is built by the subordinate class outside to monitor the authority and is the cause why resistance occurs, that is what James Scott mentioned as Hidden Transcript.

\section{Research Method}

The study done in the Semampir Sub-district of Surabaya City is using the qualitative inductive method and reflexive methodology (Alevson \& Skolberg 2000). The primary data is gained through the observation and in-depth interview that is done upon the urban poor, public figure, medical personnel, traditional healers, medical representative as the representation from the pharmaceutical industry and the secondary data gained from various sources such as the electronic media (internet or websites) as well as the non-electronic ones, like reference book, handbook, encyclopedia, dictionary, scientific journal, the results of other existing study as well as other supporting documents. The data analysis is done according to the principles of reflective perspective and critical with the strategy of understanding interpretation and presenting the fact and then doing some reflection systematically upon the first interpretation result or the reflecting to find the root and explain why it is happening. 


\section{Result and Discussion}

\section{The process of resistance on urban poor upon the modern medication}

Resistance is an attitude and action of oppositional of an individual as the product of the social interaction that is asymmetric, dominative, causing uncomfortable situation, the presence of difference importance as well as the different value and norms due to the differences in the sociocultural differences, economical condition and political position of an individual. Resistance started with the presence of critical consciousness that is built due to the external condition that is seen to be unfair, attacking and dominating so that it does not benefit the individual in gaining the right upon the condition of the body and the health. For the urban poor, critical consciousness was born due to the presence of the strong perception that the system, structure and institution of the modern medical medication rigidly has been regulated, limited and monitored even put distance of their approach upon the medical service that is qualified due to the expensive medical cost. Medical regime also intensely doing some hegemony and panoptic and putting the urban poor to the subordinated position that is demanded to always obey and follow as well as following the dominant discourse about the modern medication that is produced and internalized by the nations.

Critical consciousness of the urban poor also grew due to the feeling of marginalized by the bureaucracy culture of the modern medical service such as: regulation of health, medical rules and procedures as well as the strength of the authority of the medical institution in determining the health condition. The practice of power domination of the medical regime in the form of regulation and the monitor/surveillance that is directed to build the individual as well as the social health according to the standard of modern health that cause the cultural stutter. With the education and the knowledge of health that is so limited, the urban poor frequently face the problem especially when doing some administration in medical that is seen to be complicated and procedural when getting the modern medical treatment.

Critical consciousness built by the urban poor as the product from the reflection upon the experience, knowledge, perception and the understanding upon the reality as well as the analysis process that is done when accessing the modern medication then creating critical impression that domination, subordination, marginalization, attacking and injustice has happened in the modern medication system as expressed by the urban poor that is interviewed in this study. They mentioned that when accessing the modern medical treatment, it is found that there are lacking of quality of service that is shown with the presence of not-professional medical administration and medical personnel that is also arrogant, inaccurate diagnose, complicated medical bureaucracy, discriminative treatment, expensive cost, too long waiting time and the queue as well as the healing effectiveness that is still in question. For the urban poor, the modern medical treatment that is ineffective/ not suitable and does not make any sense has given birth to the critical consciousness that the use of the modern medical equipment with the expensive medicine apparently cannot guarantee the effectiveness of the medication, even the modern medical treatment that is accessed is causing expanding effect upon the new diagnosed disease (clinical iatrogenesis). According to urban poor, the system, structure and the institution of modern medical treatment that is accessed so far is seen to still suffer some weaknesses (modernity pathology) in the aspect of maintenance/managerial as well as the service performance. Hence, the health resistance happen is actually a reflection upon the presence of the skepticism and the distrust upon the modern medical treatment system related to the science of the modern medical, product of medicines of the pharmaceutical industry as well as the medical professional also the effectiveness of its medication (Armstrong \& Murphy 2011).

Then, the resistance happened is related with the stock of knowledge and the provocation as well as the role of the public figure and the social networking that is built by the urban poor in the social community as well as the cultural system, especially the trust system related to medical treatment that the trueness is believed for generations. Social networking developed by the urban poor and the strength of the role for the figure of the local citizen and the traditional healers, the role of religious social institution and the owning of the social position in the neighborhood, local as well as the sub- 
district level, the touch with technology of information also contribute to determine the process of resistance of urban poor upon the modern medical system.

This research proves that the health resistance of the urban poor upon the modern medical treatment system happened due to the critical consciousness that was born as the reaction upon several condition, such as the presence dominant power of medical regime through the hegemony and panoptic that has create the subordination and relation that is asymmetric. The strict manner in the regulation, procedure and authority that is applied by the medical institution also caused the urban poor to feel marginalized even alienated with the situation of institutional inside the medical that is called as bureaucracy. The impact of the dominant power in the interaction between the doctor and the patients also gives effect to the poor patient that they must bear the burden that is material and the non-material ones. Materially, the poor patient must spend their money for the medication fee that is not cheap at all. Although they see the doctor in the local clinic as well as in the hospital that are the government health facilities, yet the money they need to spend is still quite much. Especially if the patients need to stay in the hospital for the medication, the payment needed to be paid is almost certainly burdening. The additional payment usually happened because of the supporting check-up, such as the blood testing in the laboratory, phlegm test, taking picture of thorax or X-ray, X-ray for bone for the patient with uric acid, blood test for the dengue fever patients, CT scan and various kind of supporting checkups. Even sometimes, the poor patient must also spend money for quite handful to buy the medicine that is unavailable or not covered by the healthcare in the local clinic and the hospital. The limited access to the modern medication is due to the expensive cost needed because of the involvement of the industry that has trigger the occurrence of the critical consciousness to the urban poor, especially if it not balanced with the qualified and professional service as well as the guarantee upon the effectiveness result of the medication done.

The critical consciousness then create the health resistance with the support of the presence of informal network and the strong role of the local public figure in directing the choice of the medication system for the urban poor. Besides, the strong system of trust or the values of traditions that is preserved for generations and the presence of freedom and autonomy of power in producing new discourses related to the system of medication is also potentially push the rise of resistance.

\section{The background cause (bases) of the occurrence of resistance in urban poor upon the modern medical treatment system}

In the social practice of the medical world, domination, attack and injustice has happened in the relationship between the medical regime and the urban poor. The medical treatment given by the medical institution and the relation that is made with the medical personnel has created dependency and subordination, the regulation and the control, marginalization and the total obedience so that it is not putting the urban poor in favor. In the relation that is asymmetric and there is a subordination which give no chance for the urban poor to be able to participate in the decision making although it might deal with their lives. Urban poor must obey and follow the suggestion, direction, and regulation from the medical personnel while the patients also feel alienated due to the medical term, prescription, rules and regulation of medic as well as the attitude and act of the health personnel. Urban poor also mentioned that in the social-relation made, there is an impression that the medical personnel develop social distant with them. It can be observed through the attribute/clothes the health personnel wear, the way they talk, act and their behavior as well as limiting in giving the information about the health condition of the patient, treatment that is done, the benefit and the risk of the medicine given as well as the side effect of medication and so on.

Such pattern of social relation happens due to the practice of power and knowledge, followed by the presence of dependency of the patient so that it causes the obedience and tendency to follow the medical regime. The domination of authority that is based on knowledge has caused the forming of relation that is asymmetric and full of one-way information flow with the health personnel as the dominant party according to their competence and their background of knowledge. As mentioned by 
Foucault (2009) that the power that comes from knowledge has made the power smoother so that it is harder to fight. Yet, in every power there will always be a rebellion occur related to the power in itself (Muzahwi 2014).

In the social practice of the medical world, urban poor also face the injustice and ignorance for their rights in getting the qualified modern medical service. Urban poor mentioned that they have ever face a situation of dissatisfied and disappointment upon the service of the modern medical service. The works of the health personnel of administration is not professional and seemed to be arrogant as well as not so welcome and discriminate the patients, this is the reality that is found and admitted by the urban poor found for this study. Urban poor mentioned when accessing the modern medical treatment, they have ever gotten the unpleasant service, such as long line of queues, complicated medical procedure of bureaucracy that cause the alienation, limited medicine availability, generic medicine that its effectiveness is doubted even mentioned as ineffective, some patients experience allergic upon the medicine given by the doctor, the attitude of the doctor when examining the patient with their medical equipment, the doctors do not give any information about the kind of disease suffered by the patients and the act taken by the doctor and so on.

In the bureaucratic aspect and the quality of service that is still limited, seen from the complaint mentioned by urban poor related to the medication process that is failed to be understood by the poor patients, expensive price of medicine, unclear prescription and the doctors that keep giving the same medicine all over again while the old ones are not finished yet, the attitude of the personnel that is so cranky and easily triggered, the mean-looking medical administration officers as well as the high medication cost due to the supporting checkups which is expensive, the failures of medication so that the patients failed to achieve recovery and many other complaints. Although the medication system done using the advancement of technology in science of medic, but in some cases its effectiveness is still in question. The mistake and the failure in diagnose, ineffective medicine that is given which even cause more pain, dysfunction, disability, and anxiety caused by the intervention of medical technology frequently happen and felt by the patients known as clinical Iatrogenesis, which means the expansion of new pain caused by the doctor (Ilich 1976). Medicines seen to have the potential to poison and the side effect that is unwanted becomes higher along with the increase of usage.

The dominative relation, attacking and practice of injustice experienced by the urban poor has cause the birth of critical consciousness and the resistance upon the modern medication system. The resistance happened is supported by some situation, such as the strong trust system and the tradition, the role of public figure, position in social-politics as well as the social networking that is built by the urban poor, the presence of skepticism and distrust upon the modern medication system as well as various strength that is attached to the traditional/alternative medication. The development of strong trust that the disease comes from the magical creature and is supernatural pushes the urban poor to prefer the alternative/traditional medication. Foucault (1975) mentioned that the social practice in the medical world is not far from the dominant power works in the surrounding of the life of individual including in making the choice about the place to heal their disease. The act chosen is the reflection of the dominant power work in the relation that is going between the urban poor with the dominant power exist in the surrounding such as: family, neighbors, friends, traditional healers like shaman and many others (Sciortino 2000). 
Table 1.

The supporting aspect of the cause of resistance of urban poor upon the modern medication

\begin{tabular}{|c|c|c|}
\hline No. & Supporting Aspect & Explanation \\
\hline 1. & Socio-cultural & $\begin{array}{l}\text { The strong trust system and the local cultural tradition, persuasion } \\
\text { from family, friends and neighbors as well as the role of local public } \\
\text { figure and the social institution. }\end{array}$ \\
\hline 2. & Economic & $\begin{array}{l}\text { Ability of urban poor upon reaching the modern medical service is } \\
\text { limited due to the high price of the medicines and the cost of medi- } \\
\text { cal treatment because of the infiltration of the medical industry. } \\
\text { Although healthcare is provided, but the urban poor are still hardly } \\
\text { able to fulfill the payment of the healthcare because of lacking in } \\
\text { income. Besides, accessing the healthcare for the poor is getting } \\
\text { even harder because of the complication in medical bureaucracy } \\
\text { so that they prefer to avoid or do not want to deal with that at all } \\
\text { instead of stuck in such situation. }\end{array}$ \\
\hline 3. & Service quality & $\begin{array}{l}\text { The unprofessional medical service has created the dissatisfac- } \\
\text { tion and disappointment for the urban poor while accessing the } \\
\text { modern medical treatment. The mean-looking officer that is also } \\
\text { easily triggered, love to yell and is impatient, never actually smile, } \\
\text { chatty, and is discriminative and so on, is basically the reality faced } \\
\text { by the urban poor. }\end{array}$ \\
\hline 4. & Bureaucracy & $\begin{array}{l}\text { The limited education and knowledge, the urban poor feel the } \\
\text { hardship if they must deal with the medical bureaucracy. To deal } \\
\text { with the paperwork since their healthcare (BPJS) is free, the ad- } \\
\text { ministration with BPJS document and other supporting document } \\
\text { used in gaining the treatment and medication for the urban poor, } \\
\text { seen to be the hard part and causing the perception that the bu- } \\
\text { reaucracy is complicated and difficult. }\end{array}$ \\
\hline 5. & Social psychology & $\begin{array}{l}\text { The treatment of the health personnel that is unpleasant caused } \\
\text { the patients to feel offended. Besides, the traumatic feeling upon } \\
\text { the medication frequently felt by the patients when their blood is } \\
\text { taken for it gives the side effect of swollen skin. }\end{array}$ \\
\hline 6. & $\begin{array}{l}\text { Effectiveness of } \\
\text { medication }\end{array}$ & $\begin{array}{l}\text { The modern medication has not yet to give any guarantee of total } \\
\text { recovery. The believe is that the health problem cannot be entirely } \\
\text { healed through the modern medication, and that there are unan- } \\
\text { swered questions with the diagnose done. }\end{array}$ \\
\hline 7. & $\begin{array}{l}\text { The presence of } \\
\text { strength attached to } \\
\text { the traditional/alter- } \\
\text { native medication }\end{array}$ & $\begin{array}{l}\text { The creation alternative/other discourse about the medication sys- } \\
\text { tem is also triggered by the strength attached to the traditional } \\
\text { medication, such as: the service is nicer, it is not discriminative, } \\
\text { access upon it is easy, accessible almost anytime, flexible time of } \\
\text { medication, bigger chance of recovery (effective), affordable price, } \\
\text { more comfortable for the patient psychologically, do not need to } \\
\text { queue to access it, not so far from home, friendlier environment } \\
\text { that even sometimes the patients tell their complaints upon their } \\
\text { condition openly to the traditional healers. }\end{array}$ \\
\hline
\end{tabular}

In the relation context of power, resistance happen if the self-awareness of the individual occur as the subject through the process of understanding upon oneself or the technology of the self as well as the freedom and the differences in values believed or the ideology attached to oneself. Structurally and culturally, resistance happen when the modern medication system as the dominant discourse of the medical regime is not in-sync with the condition of socio-cultural and the economic attached to the urban poor. Beside the trust system that is believed, the social network developed by the urban poor and the strong role of the figure of the locals and the traditional healers, the role of the social institution of religion and the social and politic position owned by the neighborhood, local as well as the sub-district level, the touch of information technology apparently also contribute to determine the resistance process happen in the urban poor upon the modern medical system. 


\section{Form of resistance of urban poor upon the modern medication}

The practice of modern public health that is seen so far is the reflection of the power of medical regime that works through the regulation and the medical control or the surveillance upon individual and the people (Peterson \& Lupton 1996). The medical regime is intensely internalizing and directing the medical act on the modern medication, but the social-reality found indicated the presence of resistance upon the modern medication. Foucault (1984) mentioned that the power is the system of domination that tends to create discipline and control so that there is no room of freedom for the individual, but the power that is too dominant will potentially create resistance through the awareness of individual as the subject through the process of understanding upon the subject itself. For the subordinated class and the low class society, resistance is the reality commonly happened although it is seen in the cultural character, through the expression and daily activity of the society like in gossips, slanders, theme of talk, swear, satire and other behavior so that the resistance is continued in the social study.

In the practice of social in the medical world, this study found the resistance done by the urban poor. They remained silent, passive, and did not give any reaction because they realized their position and did not want to be stuck into trouble with other people, especially the medical personnel. Hence, if the urban poor feel dissatisfied or disappointed with the health personnel, they usually stay quiet and only discuss that behind the back by themselves, or with friends, neighbors or family. Even when they do not even feel comfortable with it, they will still follow the instruction of the hospital and the doctor, but behind that, the patients complained and swore and none of these was delivered to the authority of the medical institution. All the disappointment and swears are only shown to the family, neighbors, friends or other people in which actually those reflection of hatred of the urban poor is upon the attitudes of the health personnel. The attitude of the health personnel is seen to be disrespectful to the patients or discriminating the patients is frequently seen in the medical services that is given to the local clinics, hospitals, and so on. An urban poor that is interviewed in this study has experienced an uncomfortable situation or disappointment with the service given by the local health clinic, hospital, public health post, doctor, midwife, and nurses. The urban poor was resistance and expressively or emotionally delivered it to the health personnel by giving complaints, getting mad frontally to the health personal. Besides acting so expressively, the patient also told the complaints to the family, friends or other parties.

The good reaction is subordinated or the lower class, the phenomena of resistance is the reality that commonly happen (Scott 1985) and usually is cultural because the resistance occur through the expression as well as the act of daily of the people. The expressions of swearing (using expression of Surabaya's accent) is commonly expressed by the urban poor while dealing with the health personnel that they think arrogant, unfair and acting "over the top" while giving the service of the modern medication. The culture of expressive as the cultural characteristics of the people of Surabaya commonly occur in the interaction dynamic that goes in the process of medication especially when dealing with situation seen as unfair, arrogant personnel or those who undermine the patients. The uncomfortable situation in giving the service to the poor patients according to the regulation gives the implication on the dissatisfaction of the patients and weaken the trust of the urban poor upon the medical regime. When skepticism and distrust of the urban poor upon the modern medication happened, then the attitude of resistance that is implied like they remained silent and passive and only complaining inside, spreading gossips and telling it to their family, neighbors as well as the public figure up to shifting to the alternative medication that grows and rooted from the cultural situation of the people commonly chosen as well as becomes the preference in dealing with their health issue. As mentioned by Scott (1985) that the form of resistance are various, such as: (a) closed resistance (symbolic or ideological) like; gossip, slander, rejection upon the forced categories to the people and developing the low profile technique, for example: avoidance, retreat, ignorance upon the modern medication as well as staying passive according to the characteristics of low class structure, (b) semi open resistance (social protests or strike), (c) open resistance, it is one kind of resistance that is organized, systematics, and having a principle. The daily fight of the people is the symptom 
that commonly found and sometimes they forgot that the fight might not always be open because unconsciously the fight is done behind the back (unopen).

The socio-cultural context, the people of Semampir as the region of the study that is dominated by the culture of Java and Madura, swearing with harsh tone or "misuh" is not only happened in the medical world practice. In the daily social life practice, among the people of middle-low level, swearing is seen to be the habit as well as a kind of resistance upon the attitude that is seen to undermine the dignity and prestige of someone because of arrogance, act of discrimination, high-handed, rude, impolite, disrespectful, and so on. The swearing habit sometimes occur when the urban poor face the attitude of the doctor, nurses, registration officers that is seem to undermine their dignity. From the result of the study, it is found that the urban poor with the closed resistance are those who have the background as the commoners, with limited social relation, do not have any social and cultural position in their neighborhood. They usually tend to act silent and show their passive attitude when reacting and dealing with the attitude of the medical personnel that is arrogant, high-handed, unfair, and for the medical service that is seen to be not professional. Meanwhile, the urban poor who has the social, cultural, and politics position in the society act braver in doing the confrontation openly with the medical personnel that they consider unprofessional. Reaction in the form of reprimand, slur, swear, harsh words were delivered as the way to show their anger, even in some cases the urban poor dare to report the personnel to the head so that it ended with the heavy sanction given to the personnel, up to the level of firing them from the job. As what found in this study, urban poor who dare to show their semi open resistance are those who wave the social identity, such as the social cadre that also joined on of the political party, member of PKK, civil servant or the social agency staff, staff of neighborhood association (RT), social workers, officers in the sub-districts office of public relation and security division, cadre of health and environment, many others.

In the context of act of resistance upon medication done by the urban poor, they created three acts in response to the medication, those are: (a) urban poor developed skepticism and criticism upon the modern medication although they still access the modern medication, (b) they developed pluralistic or combinative medical orientation, (c) urban poor retreat themselves from the modern medication and creating alternative discourse about the medication system to achieve recovery according to the power and authority that they have. Abu-Lughod (2011) mentioned that resistance is a form of dissatisfaction upon the power or the domination that is seen too complex. Understanding resistance is a strategy to analyze and diagnose a power. This idea is actually inspired by the writing of Foucault, "where there is power, there is resistance". In the concept from Scott (1985), the form of resistance is done by the poor people in daily and the form is unopened because they unconsciously fight behind the back according to their characteristics as the low level of society.

\section{Conclusion}

Different from the stigma attached on the poor people that they are known as a group of people who are fatalist, obedient, passive and following the destiny and their lives. However, in the social practice of the medical world, it turns out the urban poor have the ability to do some self-reflection and build their critical consciousness upon the external condition that they consider unfair, attacking, and dominating them so that it is not advantageous for them and in gaining the right for the recovery of their health and body. The critical consciousness inside the mid of the urban poor is caused by the presence of system, structure, and institution of modern medical medication that rigidly regulate, limit, and monitor even give distance the reach of urban poor from the qualified medical service because of the expensive price of it. In the micro scale, the critical consciousness in the urban poor grows due to the relation that is dominative and subordinating so that it cause the weak bargaining position and the closing access for the urban poor to determine the health condition and their body condition in the process of medication and the medical treatment. For the urban poor, the modern medication is seen 
that it is not always guarantee an effective medication, instead it gives the expanding effect of the burden of new disease (clinical iatrogenesis). Critical consciousness that is built from the reflection upon their experience, knowledge, perception, and understanding upon the reality as well as the analysis process that is done by the urban poor has created skepticism and distrust upon the modern medication so that it creates resistance in the unique form that is developing the low profile technique like avoiding, retreating, fatalist and passive according to the characteristics of structure of low class society as well as persona resistance that is also spontaneous and expressive. In the context of act of resistance, urban poor is divided into three forms, those are: (a) urban poor developed skepticism and criticism upon the modern medication although they still access the modern medication, (b) they developed pluralistic or combinative medical orientation, (c) urban poor retreat themselves from the modern medication and creating alternative discourse about the medication system to achieve recovery according to the power and authority that they have.

\section{References}

Abu-Lughod (2011) The Romance of Resistance: Tracing Transformation of Power Through Bedouin Women. [Diakses 17 Juni 2011].

Agger B (2009) Teori Sosial Kritis: Kritik, Penerapan dan Implikasinya (Karya terjemahan oleh: Nurhadi). Yogyakarta: Kreasi Wacana.

Armstrong N \& Murphy E (2011) Conceptualizing Resistance. Leicester UK: University of Leicester. Chambers R (1997) Pembangunan Desa Mulai dari Belakang. Jakarta: LP3ES.

Dumm TL (1996) Michel Foucault and the Politics of Freedom. Los Angeles: SAGE.

Foucault M (2002) Power/Knowledge: Wacana Kuasa/Pengetahuan. Jakarta: Bentang Budaya.

Foucault M (1976) The Birth of the Clinic. London: Tavistock Publications Ltd.

Illich I (1995) Batas-batas Pengobatan: Perampasan Hak Untuk Sehat (karya terjemahan). Jakarta: Yayasan Obor.

Jeniet S (2010) Pola Pemanfaatan Jamkesmas di Kalangan Masyarakat Miskin di Kelurahan Wonokusumo, Semampir, Kota Surabaya. Surabaya: FISIP Universitas Airlangga.

Meyler L(1972) Side Effect of Drugs. Baltimore: Williams \& Wilkins.

Martono N (2014) Sosiologi Pendidikan Michel Foucault: Pengetahuan, Kekuasaan, Disiplin, Hukuman dan Seksualitas. Jakarta: Raja Grafindo Persada.

Muzahwi (2014) Di Balik Pelarangan Negara terhadap Prostitusi. Surabaya:FISIP Universitas Airlangga.

Nugroho H (2011) Menumbuhkan Ide-ide Kritis. Yogyakarta:Pustaka Pelajar.

Peterson A \& Lupton D (1996) The New Public Health. London: SAGE.

Piliang YA (2004) Dunia Yang Dilipat, Tamasya Melampaui Batas-batas Kebudayaan. Yogyakarta: Jalasutra.

Putra LH (2012) Pelayanan publik bidang kesehatan: Advokasi ICW untuk pasien miskin di Jabodetabek. Jurnal Politik Indonesia, 1 (2).

Sciortino R (2000) Menuju Kesehatan Madani. Yogyakarta: Pustaka Pelajar.

Scott JC (1985) Weaponsof the Weak: Everyday Forms of Peasant Resistance. Yale University Press.

Scott JC (1990) Domination and the Art of Resistance: Hidden Transcript. London: Yale University.

Weber M (1978) Economy and Society. Chicago: University of Chicago Press.

White KW (2009) In Introduction to The Sociology of Health. Thousand Oaks, New Delhi and Singapore: Sage Publications of London. (Buku ini diterjemahkan oleh Achmad Fedyani Saifuddin. Pengantar Sosiologi Kesehatan dan Penyakit. Jakarta: Rajawali Press).

Yen TS (2009) Dari Mekanisasi Sampai Medikalisasi: Tinjauan kritis Atas Pereduksian Tubuh Manusia dalam Praktik Medis. Jakarta: Dian Rakyat. 